\title{
High-gypsum Byproducts as Soil Amendments for Horticultural Crops
}

\author{
R.F. Korcak
}

Additional index words. flue gas desulfurization, fluidized bed combustion, phosphogypsum, limestone scrubber sludge, spent bed ash

Summary. The beneficial influences of gypsum on soil improvement and plant growth have been well-documented, Among these benefits are reclamation of sodic soils, alleviation of subsoil acidity problems, and contribution of $\mathrm{Ca}$ and $\mathrm{S}$ as nutrients. There are three industrial byproducts that contain significant amounts of gypsum. Phosphogypsum is probably the best-known byproduct gypsum source; the others are clean-air technology coal combustion byproducts, namely fluidized bed combustion and flue gas desulfurization residues. This review summarizes the beneficial chemical and physical effects of gypsum on soil properties and the resultant benefits on plant growth. Where applicable, emphasis is placed on potential uses and limitations of byproduct gypsum sources on horticultural crops. The potential for incorporating these materials in artificial mixtures with organic materials is discussed.

\section{Gypsum}

Gypsum $\left(\mathrm{CaSO}_{4} \cdot 2 \mathrm{H}_{2} \mathrm{O}\right)$ occurs geologically as an evaporite mineral associated with sedimentary deposits. The most-important property of gyp-

Fruit Laboratory, Beltsville Agricultural Research Center, ARS/USDA, Beltsville, MD 20705,

Use of trade names does not imply endorsement of the products named nor criticism of similar ones not named.

${ }^{\text {I}}$ Soil Scientist 
sum relating to agricultural applications is its solubility. Although sparingly soluble in aqueous solution $\left(2.5 \mathrm{~g} \cdot\right.$ liter $\left.^{-1}\right)$, gypsum is more soluble than calcite $\left(\mathrm{CaCO}_{3}\right)$ (solubility in water of 0.15 $\mathrm{mg} \cdot$ liter $^{-1}$ ) (Finck, 1982). The ascribed benefits of gypsum on soil chemical and physical properties and resultant benefits to crops are summarized in Table 1. Recent reviews on the utilization of gypsum in agriculture have been published (Oster, 1982; Shainberg et al., 1989). However, the majority of the cited literature in these reviews discuss agronomic crops.

Soil physical properties. The ameliorative effect of increased surface infiltration from surface-applied gypsum on dispersive and sodic soils is well-documented (Kemper and Noonan, 1970; Shainberg et al., 1989; Roth and Pavan, 1991). Applied gypsum decreases the exchangeable Na status of the soil and/or the electrical conductivity (U.S. Salinity Laboratory Staff, 1954). In high-Na soils with a $\mathrm{pH}$ between 8.5 and 10 , applied gypsum raises the soluble $\mathrm{Ca}^{2+}$ concentration to levels greater than that of calcite, thereby precipitating calcite. In turn, $\mathrm{pH}$ is reduced to 7.5 to 8.0, and calciteand gypsum coexist. The higher soluble $\mathrm{Ca}^{2+}$ concentrations lead to enhanced flocculation of soil colloids (Lindsay, 1979).

The effect of surface-applied gypsum $(10 \mathrm{x}$ $\left.10^{3} \mathrm{~kg} \cdot \mathrm{ha}^{-1}\right)$ on subsoil mechanical impedance 2.5 years after application to peaches (Prunus persica L.) was studied by measuring changes in cone pentrometer index (Radcliffe et al., 1986). A significant reduction in mechanical impedance was noted to a depth of $0.55 \mathrm{~m}$ within this relatively short time. The marked improvement in root restriction from the applied gypsum was associated with a chemical alteration of subsoil chemical properties, which increased root activity. Greater root activity produces organic matter, which aids in aggregation.

Soil chemical properties. The correc-

Table 1. Potential benefits of gypsum in the soil-plant system.

Physical Soil benefits
Increased infiltration
Increased aggregation
Reclamation of sodic soils
Reduced root impedance
Reduced restriction of hardpans
Chemical
Increased subsoil Ca
Reduced exchangeable Al
Plant benefits
Ca and S nutrient source
Deeper rooting
Increased tolerance to drought stress
Ca source without increasing soil pH
Long-term effects

tion of subsoil acidity has received attention because of its significant effects on plant rooting, and the worldwide occurrence of the problem. Research in this area was first initiated by Sumner (1970). The primary factor associated with subsoil acidity is the high phytotoxic level of exchangeable $\mathrm{Al}$ and, to some extent, exchangeable Mn. In most cases, these high levels of $\mathrm{Al}$ and $\mathrm{Mn}$ are related to low levels of Ca (McCray and Sumner, 1990).

Amelioration of subsoil acidity problems and corresponding increases in rooting depth, enhanced root $\mathrm{Ca}$ relationships, and resistance to drought have resulted from gypsum applications (Sumner and Carter, 1988). Both negative and positive results on plant responses have been reported (Alva et al., 1990) indicating that the chemistry of gypsum in the soil system is not yet understood completely (McCray and Sumner, 1990).

Crop responses. Gypsum provides both $\mathrm{Ca}$ and $\mathrm{S}$ for crop nutrition. Gypsum has been used as a $\mathrm{Ca}$ source for peanut (Arachis hypogaea L.), which has a high $\mathrm{Ca}$ requirement during pod development (Alva et al., 1989). However, Ca uptake depends on peanut type (Gaines et al., 1991) soil Ca status (Alva et al., 1991) and type and form of applied gypsum (Alva et al., 1989). Repeated annual applications of gypsum to peanuts have raised a concern for proper P nutrition (Sistani and Morrill, 1992) because soil buildup of excess $\mathrm{Ca}^{2+}$ may lead to reduced availability of Pas a result of the formation of calcium phosphate

Gypsum increased cauliflower (Brassica oleracea var. botrytis L.) tissue Ca levels, but had no effect on reducing tipburn, a physiological disorder associated with inadequate $\mathrm{Ca}$ nutrition (Rosen et al., 1987). The importance of gypsum being more soluble than calcite was shown by Carter and Cutcliffe (1990) in Brussels sprouts (Brassica oleracea var. gemmifera L.) grown at one site low in soil $\mathrm{Ca}$. Tissue $\mathrm{Ca}$ levels and marketable yields were significantly elevated during the first growing season after application.

Gypsum was compared to lime as a $\mathrm{Ca}$ source for blueberry (Vaccinium sp.) on upland mineral soils to separate out the $\mathrm{pH}$ effect of added lime; gypsum has little, if any, affect on soil $\mathrm{pH}$ (Korcak, 1992). Although the blueberry is considered an acid-loving plant, the results indicate a short-term tolerance for increased soil $\mathrm{Ca}$ from gypsum. The practicality of using gypsum to enhance root tolerance to high soil $\mathrm{Al}$ in acid upland soils is under further study.

Overview. The agricultural use of gypsum has been primarily in the reclamation of sodic soils. Using gypsum as an amendment for acid subsoils was initiated in the early 1970s (Shainberg et al., 1989). Research continues on the chemistry of gypsum in the soil/plant system and resultant effects on soil chemical/physical properties and crop responses. The greater mobility of $\mathrm{Ca}$ derived from gypsum vs. calcite requires the input of sufficient water for dissolution. However, in many areas where subsoil acidity problems occur-i.e., the southeastern United States and the humid areas of South America-this factor is not a limitation. However, there have been reported instances of problems created by the continuous applications of gypsum or in the use of high surface application rates (Table 2). The occurrence and extent of the problems listed in Table 2 will vary with the particular soil/plant system under study. For instance, the surface application of gypsum increases the leaching of $\mathrm{Mg}$ and $\mathrm{K}$. The induced leaching of $\mathrm{Mg}$ and $\mathrm{K}$ by gypsum in the fruit zone is beneficial to peanuts (Alva et al., 1991). However, surface application of a high gypsum byproduct within orchard tree rows resulted in sufficient leaching of $\mathrm{Mg}$ over a 6-year period to reduce significantly foliar Mg concentrations in apple (Korcak, 1988).

Although no standardized test is available presently to calculate gypsum treatment levels (Table 2), Sumner (1990) has proposed a "soil test for responsiveness to gypsum." Calibration and standardization of such a soil test and further research on a wide range of soil types both can be expected to aid in the increased utilization of gypsum as a soil amendment.

\section{Phosphogypsum}

Phosphogypsum $(\mathrm{PG})$ is a byproduct of the phosphate fertilizer industry emanating from the production of phosphoric acid from rock phosphate. The composition of PG (Table 3) varies depending on the source of rock phosphate and the particulars of the phosphoric acid manufacturing process (Mays and Mortvedt, 1986). This material normally has an aqueous $\mathrm{pH}$ between 4.5 and 5.0. Within the past 2 years, the agricultural use of $\mathrm{PG}$ was suspended due to detection on unsafe levels of radioactive radon (U.S. Gypsum Co., 1990). However, a more-recent ruling by the U.S. Environmental Protection Agency (EPA) (Federal Register, 3 June 1992) permits the controlled use of $\mathrm{PG}$ in agriculture if radon levels are $<10 \mathrm{nCi} \cdot \mathrm{g}^{-1}$. This restriction on the maximum radon concentration essentially eliminates the use of PG from southern Florida, since radon levels are commonly in the $20 \mathrm{nCi}^{-1} \mathrm{~g}^{-1}$ range; it should not have an impact on the use of PG from northern Florida or North Carolina, where radon levels are generally

Table 2. Potential problems in the utilization of gypsum in the soil-plant system.

A) Excessive soil $\mathrm{Ca}^{2+}$ buildup from repeated and/or high applications

1) Induced $P$ deficiency.

2) Excessive leaching of $\mathrm{Mg}^{2+}$ and $\mathrm{K}^{+}$ from surface horizons, particularly sandy soils.

B) Initial increase in soil salt content.

C) Lack of standardized guidelines to calculate application rates. 
Table 3. Approximate elemental composition of phosphogypsum. ${ }^{2}$

\begin{tabular}{|c|c|}
\hline \multicolumn{2}{|c|}{ Major constituents (\%) } \\
\hline Calcium & $20-24$ \\
\hline Sulfur & $15-19$ \\
\hline Phosphorus & $0.1-0.5$ \\
\hline Fluorine & $0.5-3.8$ \\
\hline \multicolumn{2}{|c|}{ Minor consituents $\left(m g \cdot \mathrm{kg}^{-1}\right)$} \\
\hline Potassium & $100-800$ \\
\hline Molybdenum & 65 \\
\hline Magnesium & $8-400$ \\
\hline Cadmium & 0.23 \\
\hline \multicolumn{2}{|c|}{ Radioactivity $\left(n C i \cdot \mathrm{kg}^{-1}\right)^{y}$} \\
\hline & 25 \\
\hline
\end{tabular}

${ }^{2}$ Values presented are an average from the following sources: Mays and Mortvedt (1986); Pavan et al. (1987, 1988); Lin etal. (1988); Alva and Sumner (1989); Alva et al. (1990); and Sumner (1990). 'Value of Mays and Mortvedt (1986) for southern Florida only.

lower (S. Richardson, personnel communication). The fate of ${ }^{226} \mathrm{Ra}$ in Florida PG was investigated by Mays and Mortvedt (1986). They surface-applied PG containing $25 \mathrm{nCi} \cdot \mathrm{kg}^{-1226} \mathrm{Ra}$ at rates up to $112 \mathrm{Mg} \cdot \mathrm{ha}^{-1}$ to a silt loam soil and successively grew corn (Zea mays L.), wheat (Triticum aestivum L.), and soybean (Glycine max L.) crops. Application of PG even at the 112 $\mathrm{Mg} \cdot \mathrm{ha}^{-1}$ rate had no effect on the radioactivity levels in grain of corn, wheat, or soybeans. The $112 \mathrm{Mg} \cdot \mathrm{ha}^{-1}$ used in this study was more than 200 times the normal rate used in peanut fertilization. Additionally, they noted no increases in grain $\mathrm{Cd}$ levels, but there was at the $112-\mathrm{Mg} \cdot \mathrm{ha}^{-1}$ rate a growth depression on corn that was ascribed to an induced Ca:Mg imbalance.

Numerous studies have shown that PG alleviates the detrimental effects of subsoil acidity on plantgrowth (Alva and Sumner, 1989; 1990) when surface-applied (Caldwell et al., 1990) or subsoiled (McCray et al., 1991). These and other studies led Sumner (1990) to conclude that there was essentially no difference between mined gypsumand $\mathrm{PG}$ regarding correction of subsoil acidity problems.

The implanted soil-mesh bag technique was used by Lin et al. (1988) to examine the effect of PG compared with lime for alleviation of poor root growth on Spodosol $\mathrm{B}_{\mathrm{h}}$-horizon soil. Amended soil in mesh bags was implanted around mature orange trees and sampled for periods up to 139 days. Bags containing $\mathrm{B}_{\mathrm{h}}$-horizon soil amended with lime had significantly higher root densities than control soils, whereas root densities in PG-amended soil bags were not significantly different from the control. Contrary to other studies, PG did not decrease exchangeable Al compared to control soils.

Phosphogypsum application to apple (Malus domestica Borkh.) trees grown on two Brazilian soils, both low in $\mathrm{Ca}$ and one high and one low in $\mathrm{Al}$, were compared to lime, $\mathrm{CaCl}_{2}$, and magnesite (a Mg-lime material) (Pavan et al., 1987). PG and lime significantly increased rooting density in the surface of the high-Al soil; this effect extended to a depth of $60 \mathrm{~cm}$ with $\mathrm{PG}$ application and to about $20 \mathrm{~cm}$ with lime. PG or lime application significantly increased fruit size and yield compared to other treatments, reflecting the enhanced rooting and perhaps increased water supply to the trees from lower in the soil profile.

Sumner (1990) compared surface-applied gypsum to mechanical mixing of soil or mechanical mixing plus lime on southeastern U.S. soils. Peaches grown on a coarse sandy loam soil with an argillic horizon in the subsoil exhibited a slight response to surface gypsum application when compared to either of the mechanical treatments. The lack of response to gypsum was accredited to the greater sensitivity of peach roots to physical barriers in contrast with chemical barriers in the subsoil. Several trials with agronomic crops showed nodifferences in response between mined gypsum and phosphogypsum.

\section{Coal Combustion Byproducts}

Overview. Fly ash produced from the burning of coal has become a generic term for all types of coal combustion byproducts. Specifically, fly ash is that portion of ash that has a sufficiently small size to be carried from the boiler in the flue gas (El-Mogazi et al., 1988). There are a number of reviews that cover the properties of fly ash and their ecological impacts (Page et al., 1979; Adriano et al. 1980; Brieger et al., 1992) and utilization in agriculture (Aitken et al., 1984; El-Mogazi et al., 1988; Haering and Daniels, 1991).

One of the limitations of the use of fly ashes in agriculture is the high concentrations of potentially phytotoxic trace elements, including $\mathrm{Se}, \mathrm{B}$, As, and Mo. In addition, fly ash may contain lesser concentrations of most other metals and radioactive elements. The concentration of these elements vary depending on type of coal used and the operating dynamics of the particular power plant. There is a strong association between fly ash particle size and trace element concentration (Davidson et al., 1974). Concentrations of $\mathrm{Se}, \mathrm{Cd}, \mathrm{As}, \mathrm{Pb}, \mathrm{Ni}, \mathrm{Cr}$, and $\mathrm{Sb}$ increased with decreasing particle size. Similarly, Phung et al. (1979) found B, Cr, Mo, Ni, As, and Se associated with fly ash panicle sizes $<53 \mu \mathrm{m}$. This association may prove beneficial for the further utilization of fly ash in agriculture, in that mechanical removal of small particles at the plant site could provide a reduced trace element material. However, this type of additional operation currently may not be feasible economically.

Annual production of coal combustion residues by the United States in the year 2000 will approach 120 million tons of fly and bottom ash and 50 million tons of flue gas desulfurization (FGD) residues (U.S. EPA, 1988). These numbers do not reflect the potential for additional residues from the stricter Clean Air Act guidelines for $\mathrm{SO}_{2}$ emissions. Compliance with reduced emission levels will, by necessity, increase the amount of FGD residues.

Two coal combustion byproducts, fluidized bed combustion materials and oxidized limestonebased scrubber sludges, account for a small portion of all coal combustion byproducts produced in the United States (Terman 1978). However, these byproducts contain appreciable quantities of $\mathrm{CaSO}_{4}$.

Fluidized bed combustion materials. Fluidized bed combustion (FBC) entails the simultaneous burning of injected coal and an absorbent, usually limestone or dolomite. During combustion, $\mathrm{CaO}$ is formed, which provides a reactive surface for $\mathrm{SO}_{2}$ absorption; thus, sulfur removal is accomplished in the furnace, and the resulting spent bed material and captured fly ash are both dry products. It has been estimated that a 1000 MW fluidized bed boiler plant would generate about 1800 tons of material per day (Ruth, 1975).

At the plant site, both the spent bed material and the captured fly ashes are mixed before disposal. The association of metals in FBC plants with the smaller fly ash particles has not been investigated, but, if the fly ash component of the process is assumed to be higher in trace elements, as discussed earlier, then separation of the spent bed ash may provide a more usable, high-gypsum agricultural material.

The dry spent bed material has an aqueous $\mathrm{pH}$ of about 12 and contains (dry weight) $52 \%$ $\mathrm{CaSO}_{4}, 33 \% \mathrm{CaO}, 0.6 \% \mathrm{CaSO}_{3}, 0.8 \% \mathrm{MgO}, 0.3 \%$ $\mathrm{NaCl}, 0.02 \% \mathrm{P}_{2} \mathrm{O}_{5}, 4.5 \% \mathrm{R}_{2} \mathrm{O}_{3}$ (primarily $\mathrm{Fe}$ and $\mathrm{Al}$ oxides), and $7 \% \mathrm{SiO}_{2}$ (Korcak, 1988). Research has been conducted on the agricultural utilization of FBC byproducts; however, in many reports, it is difficult to discern whether the material used was spent bed ash or a combination of spent bed and captured fly ash. The research performedgenerally has studied rates equal to the lime requirement of the soil or multiples thereof with corn and peanuts (Terman et al., 1978), peaches (Korcak et al., 1984; Edwards et al., 1985) forages (Stout et al., 1979) and apples (Korcak, 1979; 1980; 1982; 1984; 1985; Wrubel et al., 1982) and as an amendment for acid spoils (Sidle et al., 1979).

Utilization of high application rates of FBC materials is limited by the high alkalinity produced when the material is mixed within the soil (Terman et al., 1978). Mays et al. (1991) incorporated FBC byproducts at rates of $0,22,112$, and 560 tha $^{-1}$ to corn, soybeans, tall fescue (Festuca arundinacea), and alfalfa (Medicago sativa L.). Annual application rates up to $22 \mathrm{t}^{-1} \mathrm{a}^{-1}$ or a single application of 112 t.hat had no adverse effects on the yield of all crops tested. The highest rate led to crop failure, primarily due to high soil $\mathrm{pH}$ and very high levels of soil $\mathrm{Ca}$ and $\mathrm{S}$. The pozzolanic nature of the material created large chunks of thematerial in the field. Pozzolans are siliceous materials containing $\mathrm{Al}$ that react with $\mathrm{Ca}$ oxide to form a slow-hardening cement. 
The pozzolanic nature of FBC materials was used to benefit apple orchards (Korcak, 1988). Rates of spent bed material up to $112 \mathrm{Mg} \cdot \mathrm{ha}^{-1}$ were applied as a within-row cap in an established apple orchard. The surface-applied material formed a porous cement that prohibited weed growth for up to 4 years after application. Over 6 years, cumulative yields were increased in three of four cultivar/rootstock combinations. Foliar $\mathrm{Mg}$ levels decreased with time following high $\mathrm{FBC}$ material application, indicative of the greatly increased soil $\mathrm{Ca}$ status and the potential to leach $\mathrm{Mg}$ from the surface horizons.

These apple plots were re-examined 12 years after the initial application and 5 years after the plots were plowed (Korcak, unpublished data). $\mathrm{X}$-ray diffraction patterns of remnant cemented pieces of the applied spent bed showed that most of the original $\mathrm{CaO}$ has converted to calcium carbonate, and some quartz, gypsum, and ettringite are present (Fig. 1). The formation of calcium carbonate with time is expected and it leads to the maintenance of a relatively high $\mathrm{pH}$. Surface $\mathrm{pH}$ values from these plots after 12 years is about 7.6. Therefore, application of these materials at relatively high rates, 112 tha ${ }^{-1}$, can have long-lasting effects of the soil environment.

Similar studies using spent bed material or spent bed plus fly ash mixtures from fluidized bed combustion are underway with apples, tomatoes, and ornamental trees (my unpublished data).

For horticultural utilization, spent bed materials from FBC appear to be one of the better coal combustion products due to lower metallic contents. When not soil-incorporated, the $\mathrm{pH}$ and alkalinity effects are reduced, allowing the use of higher rates. When the situation does not warrant surface applications that can remain in place for several years, application rates need to be at or near the lime requirement of the soil to prevent detrimental effects on crop growth. A manual for calculating application rates to agricultural lands has been published (Stout et al., 1988).

As with most byproducts, the lack of quality control or lack of consistency in the material produced can have a dramatic impact on potential utilization. Boiler efficiency, source of coal, and type of sorbent can result in spent bed materials that are very different. Additionally, recycling of the bed, to increase the utilization of $\mathrm{CaO}$, can lead to lowered $\mathrm{CaO}$ content, higher gypsum content, and increased ash content. The latter also may elevate trace element content. Therefore, care is required in having test data from current production streams and an awareness of major changes in sources of materials and plant operating procedures.

Owing to the dry alkaline nature of fresh FBC materials, caution is required in land-spreading due to dust. Utilization of weathered FBC materials, which eliminates the dust problem, is currently under examination (Korcak, unpublished data). However, weathered material may not display the cement-like character of fresh material.

Flue gas desulfurization sludges. Flue gas desulfurization (FGD) byproducts (also called limestone scrubber sludges) are obtained by reaction of the flue gases with a $\mathrm{CaO}$ slurry to remove $\mathrm{SO}_{2}$ emissions. If the sludge is oxidized at the plant, the resultant material is high in $\mathrm{CaSO}_{4}$; if not, $\mathrm{CaSO}_{3}$ predominates (Terman, 1978).

The dissolution of gypsum-containing FGD materials was compared to PG and mined gypsum (Bolan et al., 1991). The three FGD materials were $99+\%$ pure gypsum, while the PG was $97.5 \%$ gypsum, compared to $82.5 \%$ gypsum in the mined material. The overriding differencewas the higher content $(12.4 \%)$ of $\mathrm{CaCO}_{3}$ in the mined gypsum. Therefore, all of the FGD materials and the PG had higher dissolution rates compared to mined gypsum. Dissolution of all samples was 3 to 8 times

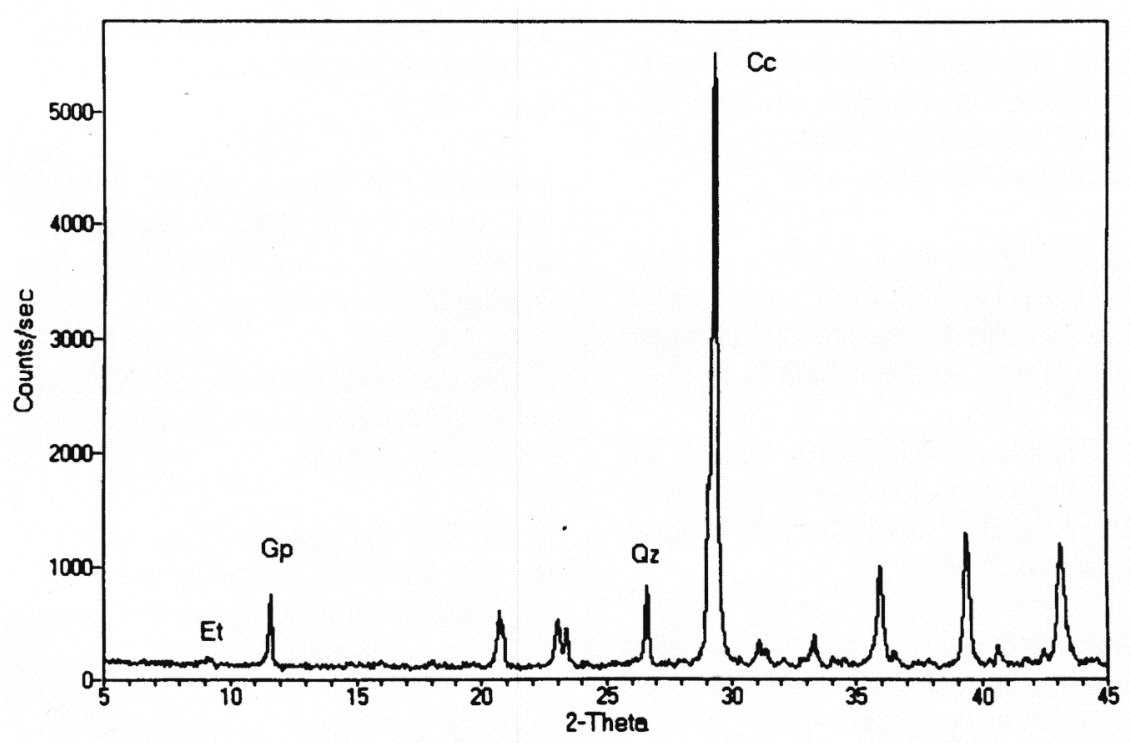

Fig. 1. X-ray diffraction pattern from a 12-year-old piece of $F B C$ spent bed material that was suface-applied and later soil-incorporated. $\mathrm{Cc}=$ calcium carbonate, $\mathrm{Qz}=$ quartz, $\mathrm{Gp}=$ gypsum, $\mathrm{Et}=$ ettringite. higher in the presence of soil than in water.

Gissel-Nielsen and Bertelsen (1988) evaluated a number of FGD products in trials with barley (Hordeum vulgare). One of these was a material obtained from coal burning and containing $10 \%$ $\mathrm{SO}_{3}^{-2} 24 \% \mathrm{SO}_{4}^{-2} 8 \%$ fly ash, and $0.5 \% \mathrm{NO}_{3} \mathrm{Al}-$ though not noted, the high amount of sulfate apparently indicates some oxidation of the material. They noted that plant Se concentrations were increased from $0.05 \mathrm{mg} \cdot \mathrm{kg}^{-1}$ in the control to 0.18 $\mathrm{mg} \cdot \mathrm{kg}^{-1}$ at the highest level, $0.5 \%$ by weight, of coal-derived FGD material. At these concentrations, Se in plants is considered an adequate source of Se for animal nutrition.

Scrubber sludge containing $4.1 \mathrm{~g} \cdot \mathrm{kg}^{-1} \mathrm{~B}$ was used to correct a B deficiency on a loamy sand soil (Ransome and Dowdy, 1987). Soybean yields were decreased during the first application year with the 10-, 20-, and 40-Mg scrubber sludge/ha applications due to elevated salt content. Yields were enhanced by scrubber sludge at all rates by the third year. Adequate soil B for soybean growth was achieved by the $20 \mathrm{Mg} \cdot \mathrm{ha}^{-1}$ application rate. The type of scrubber sludge, whether oxidized or not, was not indicated.

The data base on agricultural utilization of FGD materials, particularly well-oxidized materials, is sparse. Compared to FBC materials, oxidized scrubber sludges probably have less potential for agricultural use. Most scrubber sludges contain some fly ash, and fly ash often is added at the end of the waste stream to aid instabilization of the slurry (Terman, 1978). Scrubber sludges also must be kept from reaching an anaerobic stage due to the potential for generating hydrogen sulfide gas (Raiswell and Bottrell, 1991).

Mixtures with organic materials. There is very limited published data on the effects of mixing high-gypsum byproducts with organic materials. However, there is a growing interest in such mixtures for the retail market in the form of soil amendments or composts.

FBC materials are a potential addition to mixtures containing organic materials such as sewage sludges or sludge composts. The high $\mathrm{pH}$ on the FBC materials would assist in maintaining a low availability of heavy metals such as $\mathrm{Cd}$. A greenhouse experiment on apple seedlings was conducted using FBC spent bed ash at one or two times the soil lime requirement plus composted sewage sludge at 0,25 , or 50 dry Mt.ha ${ }^{-1}$ (Korcak, 1980). The mixtures reduced Mn uptake from a indigenously high-Mn soil and increased apple tissue $\mathrm{Ca}$ after 15 weeks. However, root $\mathrm{Cd}$ was increased by increased $\mathrm{FBC} /$ sludge compost, even though soil $\mathrm{pH}$ was maintained at 6.3 .

Further research is needed on the feasibility of using high-gypsum byproductsas components of mixtures with organic materials.

\section{Conclusion}

Gypsum has been and will continue to be an 
important soil amendment for both sodic and nonsodic soils. The beneficial effects on both soil chemical and physical properties and the longterm nature of these benefits merit its use. The two major sources of gypsum besides mined gypsum are phosphogypsum and high-gypsum byproducts derived from the burning of coal. Both of these industrial materials have limitations. Phosphogypsum, depending on rock phosphate source, may have prohibitively high radon concentrations, while coal-industry-derived gypsum may contain high levels of trace elements. However, proper selection of materials, amounts, placement, and timing of incorporation should limit potential detrimental effects in horticultural utilization,

Research with these materials on horticultural crops is lacking, particularly in situations where surface applications can be made and left in situ for long periods of time. The potential for retail marketing of soil amendments and composts derived in part from these types of materials will require continued research.

\section{Literature Cited}

Adriano, D.C., A.L. Page, A.A. Elseewi, A.C. Chang, and I. Straughan. 1980. Utilization and disposal of fly ash and other coal residues in terrestrial ecosystems: A review. J. Environ. Qual. 9:333-344.

Aiken, R.L., D.J. Campbell, and L.C. Bell. 1984. Properties of Australian fly ashes relevant to their agronomic utilization. Austral. J. Soil Res. 22:443453.

Alva, A.K. and G.J. Gascho. 1991. Differential leaching of cations and sulfate in gypsum amended soils. Commun. Soil Sci. Plant Anal. 22:11951206.

Alva, A.K and M.E. Sumner. 1989. Alleviation of aluminum toxicity to soybeans by phosphogypsum or calcium sulfate in dilute nutrient solutions. Soil Sci. 147:278-285.

Alva, A.K. and M.E. Sumner. 1990. Amelioration of acid soil infertility by phosphogypsum. Plant \& Soil 128:127-1234.

Alva, A.K, G.J. Gascho, and Y. Guang. 1989. Gypsum material effects on peanut and soil calcium. Commun. Soil Sci. Plant Anal. 20:17271744.

Alva, A.K G.J. Gascho, and Y. Guang. 1991. Soil solution and extractable calcium in gypsumamended Coastal Plain soils used for peanut culture. Commun. Soil Sci. Plant Anal. 22:99-116.

Alva, A.K., M.E. Sumner, and W.P. Miller. 1990. Reactions of gypsum or phosphogypsum in highly weathered acid subsoils. 1990. Soil Sci. Soc. Amer. J. 54:993-998.

Bolan, N.S., J.K. Syers, and M.E. Sumner. 1991. Dissolution of various sources of gypsum in aqueous solutions and in soil. J. Sci. Food Agr. 57:527541.

Brieger, G., J.R. Wells, and R.D. Hunter. 1992. Plant and animal species composition and heavy metal content in fly ash ecosystems. Water, Air, \& Soil Pollution 63:87-103.

Caldwell, A.G., R.L. Hutchinson, C.W. Kennedy, and J.E. Jones. 1990. Byproduct gypsum increases cotton yield at Winnsboro. Louisiana Agr. 33:2324.

Carter, M.R. and J.A. Cutcliffe. 1990. Effects of gypsum and mineral content of Brussels sprouts, and soil properties of Orthic Podzols. Fert. Res. 24:177-84.

Davidson, R.L., D.F.S. Natusch, J.R. Wallace, and C.A. Evans, Jr. 1974. Trace elements in fly ash. Dependence of concentration on particle size. Environ. Sci. Technol. 8:1107-1113.

Edwards, J.H., B.D. Horton, A.W. White, Jr., and O.L. Bennett 1985. Fluidized bed combustion residue as an alternative liming material and $\mathrm{Ca}$ source. Commun. Soil Sci. Plant Anal. 16:621637.

El-Mogazi, D., D.J. Lisk, and L.H. Weinstein. 1988. A review of physical, chemical, and biological properties of fly ash and effects on agricultural ecosystems. Sci. Total Environ. 74:1-37.

Finck, A. 1982. Fertilizers and fertilization. Verlag Chemie, Deerefield Beach, Fla.

Gaines, T.P., M.B. Parker, and M.E. Walker. 1991. Limestone and gypsum effects on calcium nutrition of 'Florunner' and 'NC-7' peanuts. Commun. Soil Sci Plant Anal. 22:117-135.

Gissel-Nielsen, G. and F. Bertelsen. 1988. Inorganic element uptake by barley from soil supplemented with flue gas desulphurization waste and fly ash. Environ. Geochem. Health 10:21-25.

Haering, K.C. and W.L. Daniels. 1991. Fly ash: Characteristics and use in mined land reclamation-A literature review. Va. Coal Energy J. 3:(Summer):33-46.

Kemper, W.D. and L. Noonan. 1970. Runoff as affected by salt treatments and soil texture. Soil Sci. Soc. Amer. Proc. 34:126-130.
Korcak, R.F. 1979. Fluidized bed material as a calcium source for apples. HortScience 14:163164.

Korcak, R.F. 1980. Effects of applied sewage sludge compost and fluidized bed material on apple seedling growth. Commun. Soil Sci. Plant Anal. 11:571585 .

Korcak, R.F. 1982. Effectiveness of fluidized bed material as a calcium source for apples. J. Amer. Soc. Hort. Sci. 107:1138-1142.

Korcak, R.F. 1984. Utilization of fluidized bed material as a calcium and sulfur source for apples. Commun. Soil Sci. Plant Anal. 15:879-891.

Korcak, R.F. 1985. Effect of coal combustion waste used as lime substitutes on nutrition of apples on three soils. Plant Soil 85:437-441.

Korcak, R.F. 1988. Fluidized bed material applied at disposal levels: Effects on an apple orchard. J. Amer. Soc. Hort. Sci. 113:189-193.

Korcak, R.F. 1992. Short-term response of blueberry to elevated soil calcium. J. Small Fruit Viticult. 1. (In press.)

Korcak, R.F., J.J. Wrubel, Jr., and N.F. Childers. 1984. Peach orchard studies utilizing fluidized bed material. J. Plant Nutr. 7:1597-1604.

Lin, Z., D.L. Myhre, and H.W. Martin. 1988. Effects of lime and phosphogypsum on fibrous citrus-root growth and properties of Spodic horizon soil. Soil Crop Sci. Soc. Fla. Proc. 47:67-72.

Lindsay, W.L. 1979. Chemical equilibria in soils. Wiley \& Sons, New York.

Mays, D.A. and J.J. Mortvedt 1986. Crop response to soil applications of phosphogypsum. J. Environ. Qual. 15:78-81.

Mays, D.A., P.M. Giordano, and A.D. Behel, Jr. 1991. Impact of fluidized bed combustion waste on metal content of crops. Water, Air, \& Soil Pollution 57-58:307-317.

McCray, J.M. and M.E. Sumner. 1990. Assessing and modifying $\mathrm{Ca}$ and $\mathrm{Al}$ levels in acid subsoils. Adv. Soil Sci. 14:45-75.

McCray, J.M., M.E. Sumner, D.E. Radcliffe, and R.L. Clark 1991. Soil Ca, Al, acidity and penetration resistance with subsoiling, lime and gypsum treatments. Soil Use Mgt. 7:193-199.

Oster, J.D. 1982. Gypsum usage in irrigated agriculture: A review. Fert. Res. 3:73-89. 
Page, A.L., A.A. Elseewi, and I.R. Straughan. 1979. Physical and chemical properties of fly ash from coal-fired power plants with reference to environmental impacts. Residue Rev. 71:83-120.

Pavan, M.A., F.T. Bingham, and F.J. Peryea. 1987. Influence of calcium and magnesium salts on acid soil chemistry and calcium nutrition of apple. Soil Sci. Soc. Amer. J. 51:1526-1530.

Phung, H.T., L.J. Lund, A.L. Page, and G.R. Bradford. 1979. Trace elements in fly ash and their release in water and treated soils. J. Environ. Qual. 8:171-175.

Radcliffe, D.E, R.L. Clark, and M.E. Sumner. 1986. Effect of gypsum and deep-rooting perennial on subsoil mechanical impedance. Soil Sci. Soc. Amer. J. 50:1566-1570.

Raiswell, R. and S.H. Bottrell. 1991. The disposal of flue gas desulphurisation waste: Sulphur gas emissions and their control. Environ. Geochem. Health 13:119-126.

Ransome, L.S. and R.H. Dowdy. 1987. Soybean growth and boron distribution in a sandy soil amended with scrubber sludge. J. Environ. Qual. 16:171-175.

Rosen, C.J., H.J. Buchite, and G.G. Ahlstrand. 1987. Cauliflower response to gypsum on a coarse-texturedsoil: Relationship between tipburn and leaf nutrient distribution. J. Plant Nutr. 10:1925-1934.

Roth, C.H. and M.A. Pavan. 1991. Effects of lime and gypsum on clay dispersion and infiltration in samples of a Brazilian Oxisol. Geroderma 48:351361.

Ruth, L.A. 1975. Regeneration of $\mathrm{CaSO}_{4}$ in FBC. Proc. Fourth Intl. Conf. on Fluidized-bed Combustion. The MITRE Corp., McLean, Va. p. 425-438.

Shainberg, I., M.E. Sumner, W.P Miller, M.P.W Farina, M.A. Pavan, and M.V. Fey. 1989. Use of gypsum on soils: A review. Adv. Soil Sci. 9:1-111.

Sistani, K.R. and L.G. Morrill 1992. Foliar application of phosphorousand residual effect of gypsum on peanuts. J. Environ. Sci. Health A27:317-327.
Sidle, R.C., W.L. Stout, J.L. Hern, and O.L. Bennett. 1979. Solute movement from fluidized bed combustion waste in acid soil and mine spoil columns. J. Environ. Qual. 8:236-241.

Stout, WL., J.L. Hern, R.F. Korcak, and C.W. Car/son. 1988. Manual for applying fluidized bed combustion residue to agricultural lands. ARS/ USDA ARS-74.

Stout, W.L., R.C. Sidle, J.L. Hern, and O.L. Bennett. 1979. Effects of fluidized bed combustion waste on the $\mathrm{Ca}, \mathrm{Mg}, \mathrm{S}$, and $\mathrm{Zn}$ levels in red clover, tall fescue, oat, and buckwheat. Agron. J. 71:662-665

Sumner, M.E. 1970, Aluminum toxicity-A growth limiting factor in some Natal sands. Proc. South African Sugar Tech. Assn. 44:197-203.

Sumner, M.E. 1990, Gypsum as an amendment for the subsoil acidity syndrome. Final Rpt., Project \#83-01-024R, Florida Inst. Phosphate Res., Bartow.

Sumner, M.E. and E Carter. 1988. Amelioration of subsoil acidity. Commun. Soil Sci. Plant Anal. 19:1309-1318.

Terman, G.L. 1978. Solid wastes from coal-fired power plants: Use or disposal on agricultural lands. Tennessee Valley Authority, Muscle Shoals, Ala. Bul. Y-129.

U.S. Environmental Protection Agency 1988. Wastes from the combustion of coal by electric utility power plants. EPA/530-DW-8-002.

U.S. Gypsum Company. 1990. Farewell, phosphogypsum. Agrichem. Age 34(5):17,20,30.

U.S. Salinity Laboratory Staff. 1954. Diagnosis and improvement of salineand alkali soils. USDA Agr. Hdbk. 60.

Wrubel, J.J., Jr., R.F. Korcak, and N. Childers. 1982. Orchard studies utilizing fluidized bed material. Commun. Soil Sci. Plant Anal. 13:10711080. 